

\title{
El extraordinario caso de la ciudad lineal de Tokaido The Extraordinary Case of Tokaido
} Linear City

\author{
José Durán Fernández, Juan Pedro Romera Giner \\ Universidad Politécnica de Valencia (UPV), ETSAV \\ Traducción Translation Jacinta Harrington-Flynn
}

\section{Palabras clave Keywords}

Mobilidad, paso peatonal, Hishikawa Moronobu, Japan, Tokugawa era

Mobility, pedestrian passageway, Hishikawa Moronobu, Japan, Tokugawa era

\section{Resumen}

Durante trescientos años de la historia nipona reciente se produjo un evento urbano extremadamente original y antecesor de las ciudades-región de la actualidad. A este evento urbano se le ha llamado en esta investigación 'la ciudad lineal de Tokaido' y aconteció entre los siglos XVII y XIX, un periodo de paz y aislamiento en Japón que aportaría una estructura urbana inédita en el mundo. Esta investigación analiza, trabajando sobre los precisos mapas pictóricos de Hishikawa Moronobu y otros documentos gráficos, esta estructura urbana lineal de quinientos kilómetros de longitud que cruzaría el país de parte a parte uniendo sus dos capitales y con una población cercana a los dos millones de habitantes. Y demuestra la continuidad urbana que la convierte en ciudad lineal. El artículo es un ensayo gráfico formado por pequeños capítulos que sumergirán al lector en una época del Japón ya urbana cuando Europa era todavía preurbana.

\section{Abstract}

During 300 years of the recent Japanese history, a very original urban event took place becoming a predecessor of today's region-cities. This urban event will be referred to in this research as 'Tokaido Linear City' and occurred between the 17th and 19th Century, a time of peace and isolation in Japan that would contribute to an unprecedented and global urban structure. This research analyses, working with precise pictorial maps by Hishikawa Moronobu and other graphic documents, this five-hundred-kilometre urban linear structure that would cross the country from side to side connecting the two capitals with a population close to 2 million. This is a graphic work, made up of small chapters that will immerse the reader in an already urbanised Japan by the time Europe was still pre-urban. 
Desplazamientos nacionales. Antes de sumergirnos en la ciudad lineal de Tokaido conviene detenernos brevemente en el estudio de las estructuras nacionales de movilidad del país nipón en su historia reciente, pues la ciudad lineal de Tokaido tuvo un pasado de carretera radial y tiene un presente que forma parte de un sistema en red. Y por tanto siempre existió, aunque formando parte de estructuras distintas.

En la figura 1 se representan las tres grandes estructuras nacionales de carreteras en los tres últimos grandes períodos del Japón. La forma de la red en los tres períodos es notablemente distinta; a razón de lo que se observa en el documento, el sistema de carreteras nacional ha evolucionado desde un esquema centralizado hacia un sistema en red, con el objetivo de alcanzar la máxima conectividad del territorio.

Desde el siglo viII hasta el siglo xvi Japón vertebra la movilidad de su territorio por medio de un sistema radial con centro en la capital. Seis carreteras irradian de la antigua capital Kioto, tres se dirigen hacia el norte y tres hacia el sur. Pero con la instauración del régimen Tokugawa a comienzos del siglo xvir y el traslado de la capital a Edo (Tokio), la configuración del sistema de carreteras cambia radicalmente, transformándose en un sistema circular.

Los desplazamientos nacionales ya no responden a un patrón de movimientos del centro a la periferia y viceversa, sino que, debido a la polarización del territorio por la existencia de dos centros urbanos nacionales, Kioto y Edo, el movimiento de personas se produce de centro a centro, como estudiaremos a continuación. El final del proceso de descentralización territorial lo traerá el siglo $\mathrm{xx}$, con la desaparición de la línea $\mathrm{o}$ los desplazamientos unidireccionales y la construcción de un sistema de carreteras en red, aún inacabado, que conectará eficazmente todas las ciudades del país. (1)
Fig. 1. Comparación del sistema de carreteras en Japón en distintas épocas. Dibujo de los autores, 2015.

National Mobility. Before immersing ourselves in the Tokaido Linear City, we should pause for a moment in the study of the national mobility structures in Japan's recent history, since the Tokaido Linear City had a past and present in radial roads belonging to a network system. Therefore, it always existed although part of a different structure.

Figure 1 represents the three great national road structures in the last three major periods in Japan. The shape of the network is notably different; and by observing the document, the reason is that the national road system has evolved from centralised roads to a network system to achieve maximum land connectivity.

From the 8 th to 16 th Century Japan organised its territorial mobility with a central system. Six roads radiated from the former capital of Kyoto, three running north and three running south. However, due to the establishment of the Tokugawa Regime at the beginning of the 17th Century and the transfer of the capital to Edo (Tokyo) the road system changed radically, becoming circular.

The movements no longer responded to a pattern of direction from the centre to periphery and vice versa. Because of the polarization of the territory with the existence of two national urban centres, Kyoto and Edo, the movement of people was produced from a centre to another centre as it will be shown. The end of territorial decentralisation will come in 20th Century with the disappearance of the line or one-way movements and the construction of a net of roads, still incomplete, that will efficiently connect the cities in the country. (1) 


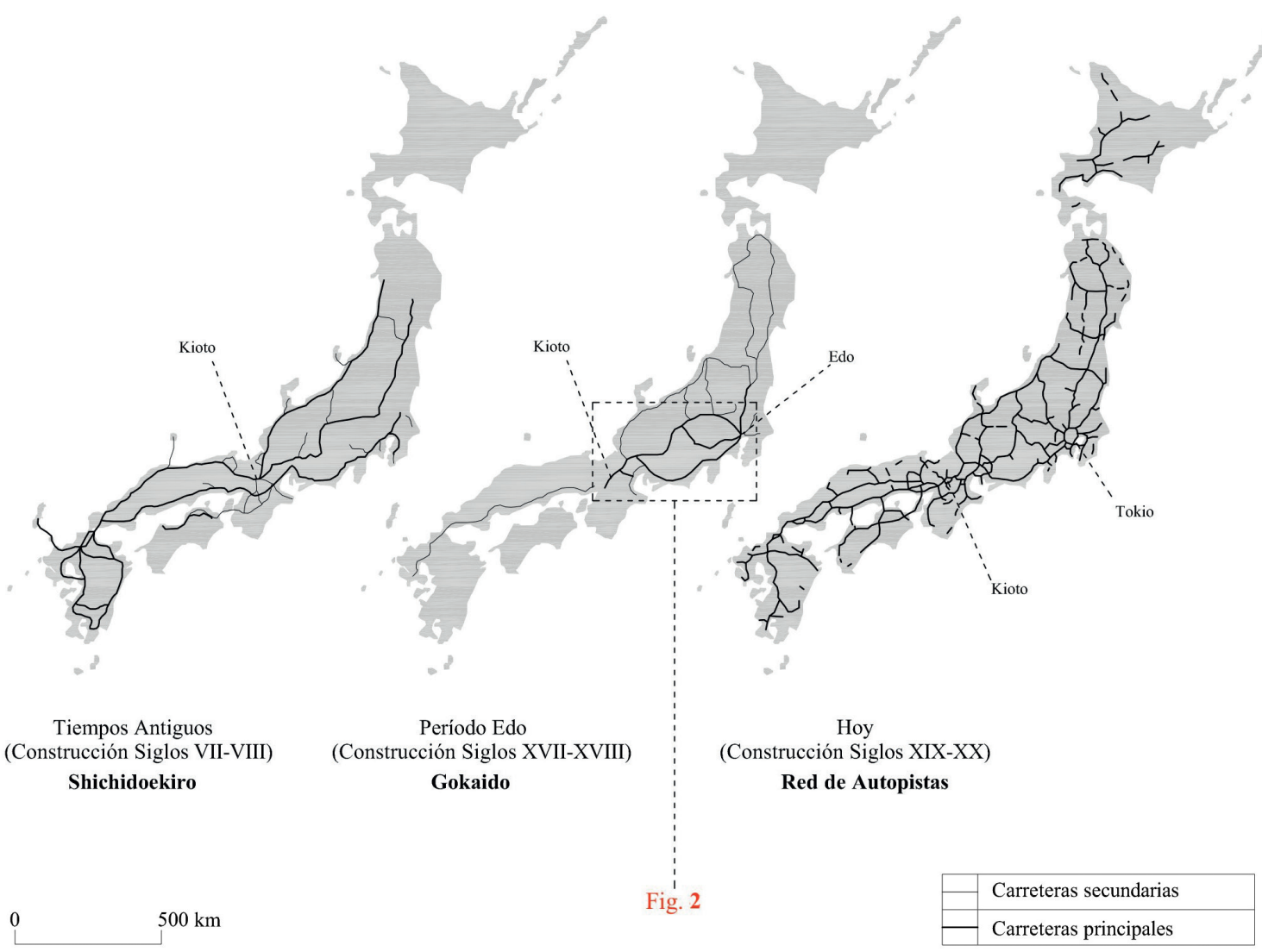

A Huge Circular Pedestrian Linear City. On the large ring that connects Edo and Kyoto, a surprising urban event takes place in the circular system of roads from the Tokugawa era: the shaping of a huge circular pedestrian linear city of roughly $1000 \mathrm{~km}$ in length being the maximum expression of Japanese urban linear space. (2) During the Tokugawa period only a very small part of the Japanese population travelled by palanquin, horse, or ox-cart, mobility was on foot in the city itself and journeys throughout the country.

Figure 2 shows a drawing of the great urban ring that connects both cities. The circuit consists of a route running north that passes through the interior of the country and the other running south parallel to the coast, like two arches, one concave, the other convex, joined in their extremes. (3) Both routes were created for military purposes, like Roman roads, so that the civil servants of the state (samurai warriors, feudal lords, collectors and messengers) could travel the domains of the feuds under the protection of the Shogunate. (4) Unlike the Roman roads, however, the Tokaido route shaped a continuum built along its path, a linear city as shown in this research.

The map displays the 120 cities the Tokugawa regime created to help travellers during their journey. Built as small towns on the edges of the road that would serve as customs control, rest areas and changes in staging posts, they quickly became (due to the steady flow of thousands of travellers) cities of 1000 and 10000 inhabitants very close to each other. The detailed structure of this linear circular city can be seen in the study of the southern route, the Tokaido road. 
Enorme ciudad lineal circular peatonal. En el sistema circular de carreteras del período Tokugawa, a lo largo del anillo que conecta las ciudades de Edo y Kioto, se produce un acontecimiento urbano sorprendente: la formación de una enorme ciudad lineal circular peatonal de aproximadamente $1000 \mathrm{~km}$ de longitud, y que es la máxima expresión del espacio lineal urbano japonés. (2) En tiempos de los Tokugawa solo una pequeña parte de la población del Japón viajaba en palanquines, a caballo o en carros tirados por bueyes, la movilidad residía en la marcha a pie, tanto en la propia ciudad como en los desplazamientos nacionales.

En la figura 2 se ha dibujado el gran anillo urbano que conecta ambas ciudades. El circuito está formado por una ruta al norte que discurre por el interior del país y otra al sur que corre paralela a la costa, como dos arcos, uno cóncavo y otro convexo, que se unen en sus extremos. (3) Ambas rutas fueron creadas con fines militares, como las calzadas romanas, para que funcionarios del estado (guerreros samurai, señores feudales, recaudadores y mensajeros) recorrieran los dominios de los distintos feudos bajo la protección del Shogunato. (4) Pero a diferencia de las calzadas romanas, la ruta Tokaido formó un continuo construido a lo largo de su recorrido, una ciudad lineal, como se demuestra en esta investigación.

En el plano se han marcado las 120 ciudades que el régimen Tokugawa ordenó crear para asistir al viajero durante el trayecto, en un inicio pequeñas poblaciones en los bordes de la carretera que servían de control aduanero, de estaciones de descanso y cambio de postas, y que, en poco tiempo, debido al intenso trasiego de miles de viajeros, se convirtieron en ciudades de entre 1.000 y 10.000 habitantes, muy próximas unas de otras. Veamos en detalle la estructura de esta ciudad lineal circular por medio del estudio de la ruta sur, la carretera Tokaido.

Tokaido. Para comprender la estructura de esta enorme ciudad lineal se ha recurrido al estudio del mapa pictórico que muestra la ruta Tokaido en
Fig. 2. Enorme ciudad lineal circular peatonal. Siglos XVII a XIX. Sistema de carreteras en la época premoderna, uniendo Edo y Kioto. Ruta Nakasendo y Ruta Tokaido. Dibujo de los autores.

Tokaido. The study of the pictorial map showing the Tokaido route in 1690 drawn by Hishikawa Morono, allows understanding the structure of this enormous linear city. (5) The map is a piece of unusual beauty, perfectly combining cartography and pictorial vision in a continuous, long and narrow drawing, as a film sequence shot where the movements of the travellers along the long route are told. (Fig. 3)

It is perhaps a cartography document on the same level as the Plan of Rome drawn by Giambattista Nolli between 1736 and 1748. Both are contemporary cartographies that show very clearly the space of an urban phenomenon. Nolli sketched the surprising emptiness of Rome and Moronobu sketched the never-ending line of the city of Tokaido. Let's observe the Moronobu Map.

The precision of this figure [see figure 3] (drawn on a horizontal scale of 1:12 000) provides a very precise idea of the structure and the components of this astonishing linear city and national infrastructure, a clear antecedent of the Linear City by Arturo Soria in 1870 and later developed by Ludwig Hilberseimer during 20th Century but with the difference that they were partially tested whereas the Tokaido Linear City was a reality for almost 300 years. (6)

This figure shows how the route began and ended in two great cities, Edo or Kyoto, and in its route along its almost $500 \mathrm{~km}$ crossed several hundred towns. The distribution of the cities along the line followed a certain spatial hierarchy based on the type of settlement. On average, the structure included a castle city (11 units) every 


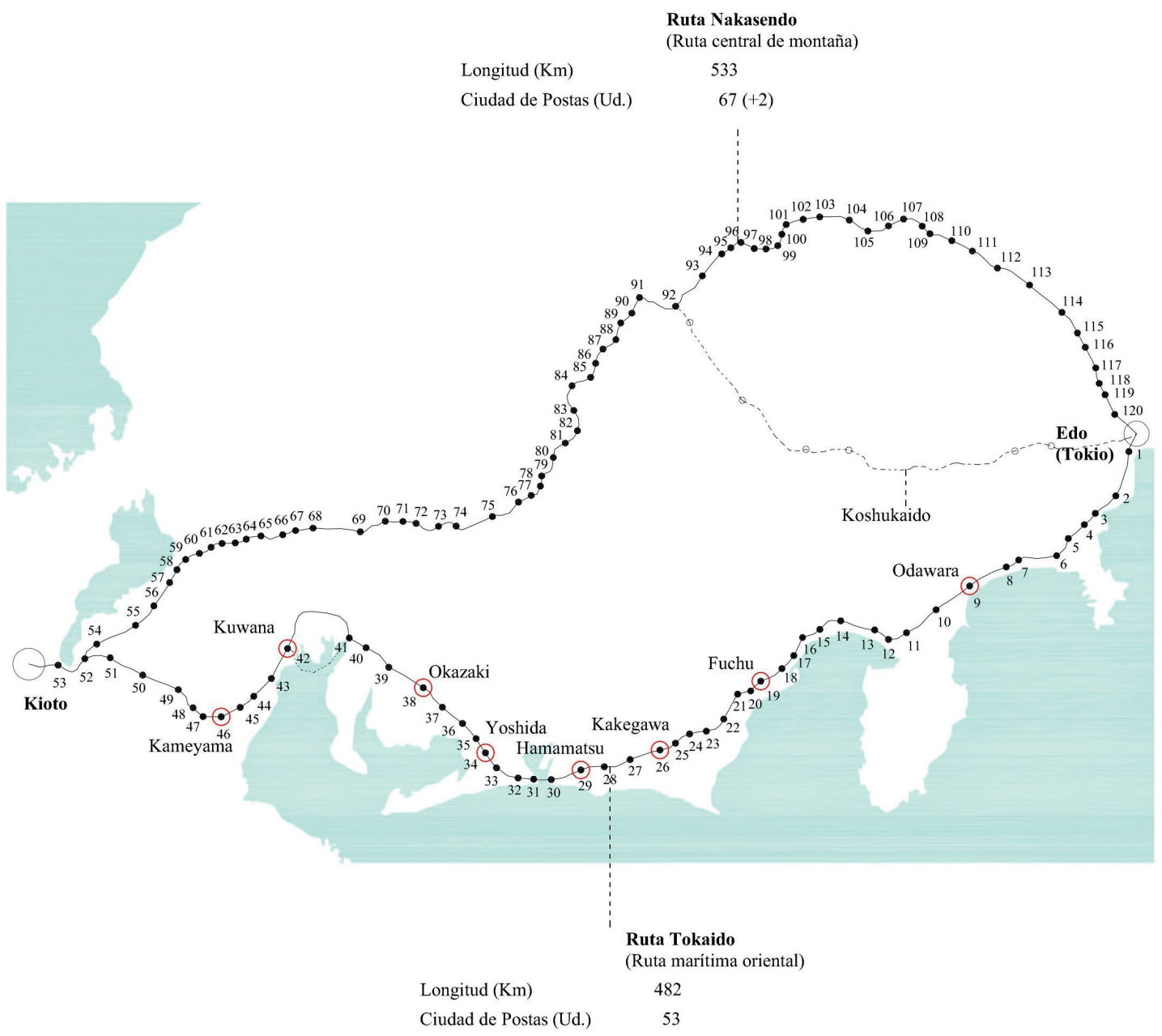

$50 \mathrm{~km}$, a station city (52 units) every $10 \mathrm{~km}$ and a town (341 units) every kilometre. In total, the linear city is made up of 396 urban centres, including Edo and Kyoto at opposite ends and including the castle cities as part of the station cities.

Linear City of 1,6 Million Inhabitants. The map shows that an urban centre is passed through at each kilometre, and according to the data taken from figure 4, presenting the number of inhabitants of each of the 53 cities in 1843, more than 1,6 million people lived in the Linear City of Tokaido.

The 53 cities of the route, called shukuba machi (city of posts), reached an average of 3700 inhabitants and some of the castle cities joka machi, exceeded more than 10000 . It became a military route and safe passage with 53 custom controls for the regular trips to the capital made by the feudal lords, however, with time, it turned into a mainly commercial route. (7)

The cities received thousands of travellers; so much so that $10 \%$ of the buildings of these cities were allocated for lodging and, in some cases, even exceeded $25 \%$. This linear city of 1,6 million inhabitants was the result of a complex set of very specific historical circumstances, but above all, it was the intense movement of travellers from city to city and inn-to-inn that made it what it was: 
1690, dibujado por Hishikawa Moronobu. (5) El mapa es de una belleza inusual, combina a la perfección la precisión cartográfica y la visión pictórica en un dibujo continuo, largo y estrecho, a modo de un plano-secuencia cinematográfico donde se relata el movimiento de los viajeros a lo largo de la dilatada ruta. (Fig. 3)

Es quizá un documento cartográfico a la altura del plano de la ciudad de Roma dibujado por Giambattista Nolli entre 1736 y 1748 . Ambas son obras cartográficas coetáneas que enseñan con absoluta rotundidad el espacio de un fenómeno urbano. Nolli dibuja el sorprendente vacío de la ciudad de Roma, y Moronobu dibuja la interminable línea de la ciudad de Tokaido. Veamos el plano de Moronobu.

La precisión de la figura [ver figura 3] -dibujada a escala 1:12.000 en sentido horizontal- permite hacernos una idea muy rigurosa de la estructura y los componentes de esta asombrosa ciudad lineal e infraestructura nacional, un claro antecedente de las ideas de ciudad lineal de nuestro Arturo Soria en 1870 y posteriormente desarrollada por Ludwig Hilberseimer, bien entrado el siglo $\mathrm{xx}$, pero con la diferencia de que si aquéllas fueron ensayadas parcialmente, la ciudad lineal Tokaido fue una completa realidad durante cerca de 300 años. (6)

En esta figura se muestra cómo la ruta comenzaba y finalizaba en una gran urbe, sea Edo o Kioto, y en su recorrido a lo largo de sus cerca de $500 \mathrm{~km}$, atravesaba varios cientos de poblaciones. La distribución de las ciudades a lo largo de la línea cumplía una cierta jerarquía espacial, en base al tipo de asentamiento. El sistema consistía en una media de una ciudad-castillo ( $11 \mathrm{uds}$.) cada $50 \mathrm{~km}$, una ciudad-estación (53 uds.) cada $10 \mathrm{~km}$ y un pueblo (341 uds.) cada kilómetro. En total, la ciudad lineal estaba formada por 396 núcleos urbanos, contando con Edo y Kioto en sus extremos e incluyendo las ciudades-castillo como parte de las ciudades-estación.
Fig. 3. Ruta Tokaido en la época Edo. Elaboración de los autores sobre los planos base: Tokaido bunkenzu 1-bu o motte 1-cho ni ateru. Genroku 3, por Hishikawa Moronobu, 1690. Montaje de 73 planos incluidos en el volumen formado por 5 secciones. Fuente: Tokyo National Museum.

"Pilgrimages were the most tolerated travel purpose by the Japanese government, as it was difficult to deny travel permission for religious reasons. As a result, pilgrimages were a very common pretext to travel reaching around 400000 to 500000 people in specific season such as New Year". (8)

It is in figure 5 where we understand from the graphic documents made by Moronobu, the hierarchy of the urban centre and its great proximity. The figure shows the urban density of the so-called linear city in this research.

Built Pedestrian Corridor. German Doctor and Naturalist Engerbelt Kaempfer, travelled Tokaido route several times between 1690 and 1692, and after returning to Europe he left written documentation where he described with incredible detail what he had observed throughout his trips along the route. He was fascinated by how crowded the road was, so much so that in his writings he compared it to the most populous streets in Europe. Kaempfer described exactly what entails a linear city:

"[...] Most towns have just one long street, bordered at each side of the road, towns sometimes extend such a length that they reachesthe next town in a quarter of a mile $(400 \mathrm{~m})$, roughly".

Kaempfer described the route as an almost continuous built pedestrian corridor since on certain occasions the limits of the towns were barely 400 metres distant. So, as soon as they extended a little along the road, the Tokaido route 


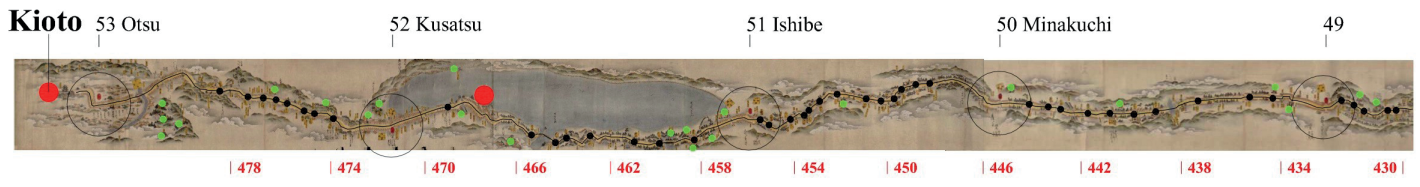

49 Tsuchiyama

48 Sakanoshita 47 Seki

46 Kameyama

45 Shono 44 Ishiyakushi

43 Yokkaichi
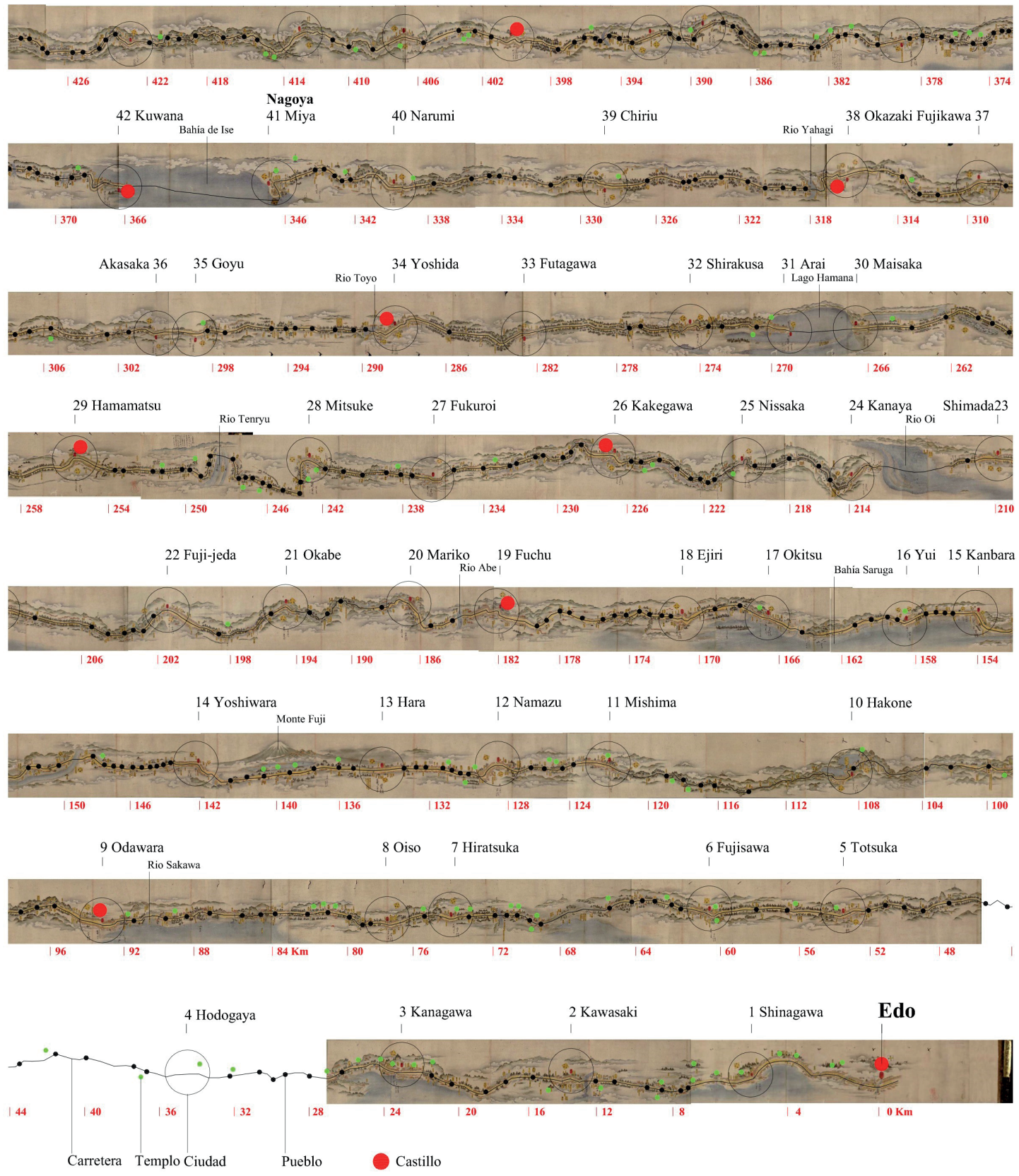
Ciudades Habitantes

\section{EDO (Tokio)}

Shinagawa

Kawasaki ( $r$ )

Kanagawa ( $r$ )

Hodogaya

Totsuka

Fujisawa

Hiratsuka

Oiso

Odawara (c/r)

Hanoke

Mishima

Numazu (c)

Hara

Yoshiwara ( $r$ )

Kambara (c)

Yui

Okitsu

Ejiri

Fuchu (c)

Mariko

Okabe

Fujieda

Shimada ( $r$ )

Kanaya

Nissaka

Kakegawa (c)

Fukuroi

Mitsuke

Hamamatsu (c)

Maisaka

Arai

Shirasuka

Futagawa

Yoshida (c)

Goyu

Akasaka

Fujikawa

Okazaki ( c )

Chirifu

Narumi

Miya (c )

Kuwana (c )

Yokkaichi

Ishiyakushi

Shono

Kameyama (c)

Seki

Sakanoshita

Tsuchiyama

Mizuguchi (c)

Ishibe

Kusatsu (c )

Otsu

KYOTO

Total

Media Shukuba Machi

1150000

6890

2433

2982558

$2906 \quad 613$

$4089 \quad 913$

$2114 \quad 443$

$3056 \quad 676$

$5404 \quad 1542$

$844 \quad 197$

$4048 \quad 1025$

$5346 \quad 1234$

$1939 \quad 398$

$2832 \quad 653$

$2480 \quad 509$

$713 \quad 160$

$1668 \quad 316$

$6498 \quad 1340$

$14071 \quad 3673$

$795 \quad 211$

$2322 \quad 487$

$4425 \quad 1061$

$6727 \quad 1461$

$4271 \quad 1004$

$750 \quad 168$

3443960

$843 \quad 195$

$3935 \quad 1029$

$5964 \quad 1622$

$2475 \quad 541$

$3474 \quad 797$

$2704 \quad 613$

$1468 \quad 328$

$5277 \quad 1293$

$1298 \quad 316$

$1304 \quad 349$

$1213 \quad 302$

$6494 \quad 1565$

$1620 \quad 292$

$3643 \quad 847$

$10342 \quad 2924$

$8848 \quad 2544$

$7114 \quad 1811$

$991 \quad 241$

$855 \quad 211$

$1549 \quad 567$

1942632

$564 \quad 153$

$1505 \quad 351$

$2692 \quad 692$

$1606 \quad 458$

$2351 \quad 586$

$14892 \quad 3650$

290000

1635802

3694,38
Fig. 4. NOMIKOS, C: Ciudades, población, número de viviendas y número de hoteles de la ciudad lineal de Tokaido en 1843. (c) Ciudad castillo, (r) Ciudad portuaria. Nomikos Vaporis, Constantine.'Overview of Tokaido Post Stations (1843)'. Breaking Barriers: Travel and State in Early Modern Japan, 1994.
Fig. 5. Página siguiente. Ciudad lineal de 1,6 millones de habitantes, 1690. Diagrama de los distintos asentamientos urbanos de la ruta Tokaido. Plano base [ver figura 3]. Dibujo de los autores. 


\section{Kioto}

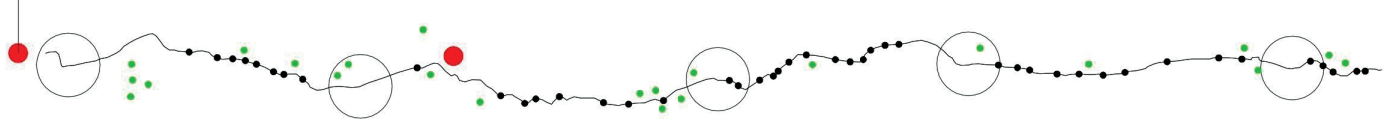

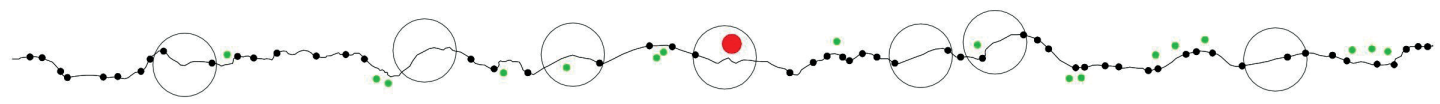

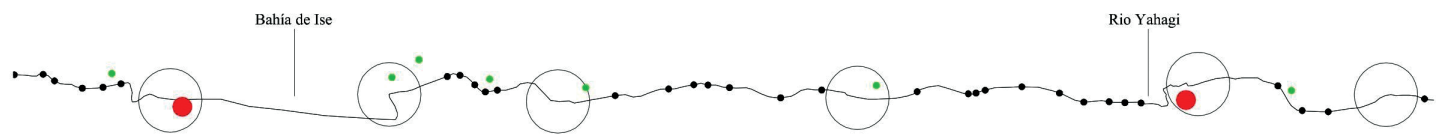

Rio Toyo Lago Hamana

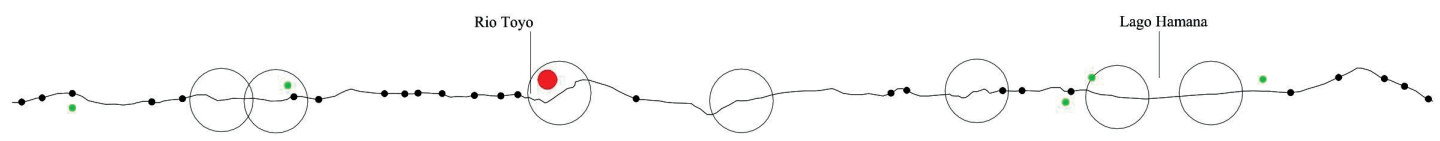

Rio Tenyu
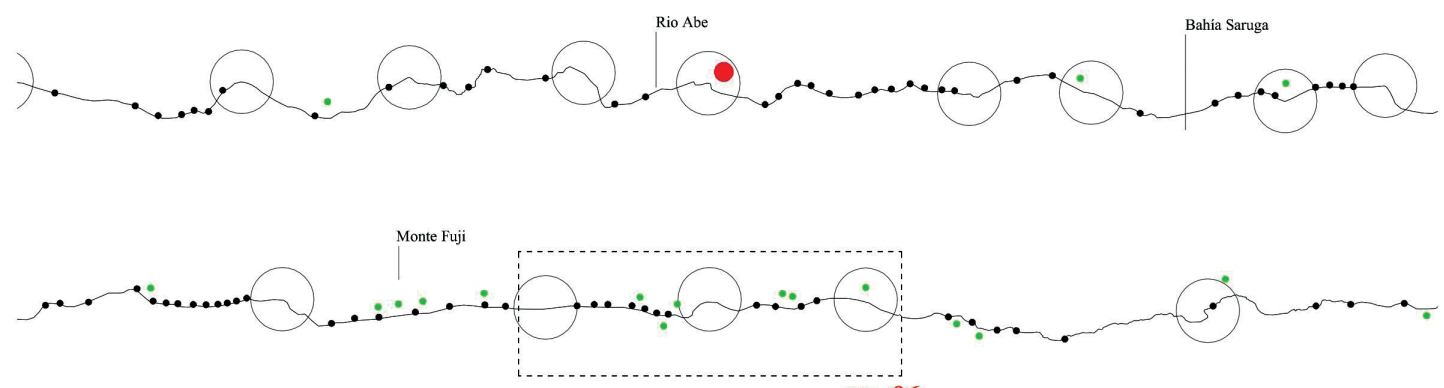

Fig. 06

Rio Sakawa

Edo
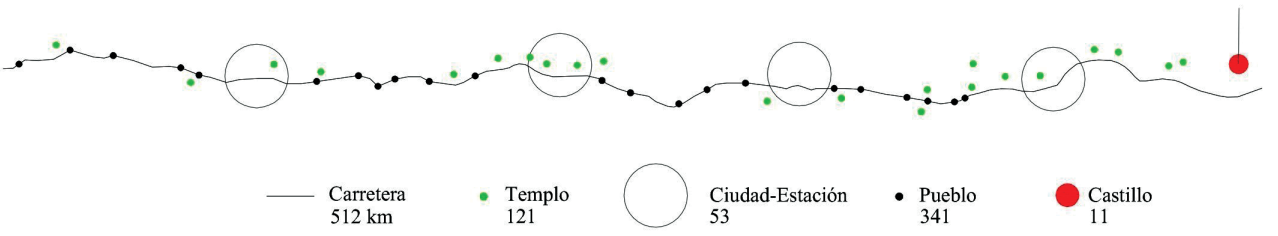
Ciudad lineal de 1,6 millones de habitantes. Esto indica que cada kilómetro recorrido se atravesaba un núcleo urbano, y atendiendo a los datos extraídos de la figura 4, que expone el número de habitantes de cada una de las 53 ciudades en 1843, en la ciudad lineal Tokaido vivían más de 1,6 millones de personas.

Las 53 ciudades de la ruta, llamadas shukuba machi (ciudad de postas), alcanzaron de media los 3.700 habitantes, y algunas ciudades castillo, joka machi, superaron ampliamente los 10.000 habitantes. Comenzó siendo una ruta militar y una vía segura con 53 aduanas para los viajes periódicos de los señores feudales a la capital, pero con el tiempo se convirtió en una ruta fundamentalmente comercial. (7)

Las ciudades eran receptoras de miles de viajeros; tanto era así que el $10 \%$ de las construcciones de estas ciudades estaban destinadas a la hospedería, y en algunos casos alcanzaba tal alto grado en esta especialización que ciertas ciudades incluso superaban el 25\%. Esta ciudad lineal de 1,6 millones de habitantes es producto de un complejo conjunto de circunstancias históricas muy determinadas, pero por encima de todas fue el intenso movimiento de viajeros de ciudad en ciudad y de posada en posada lo que la creó:

"El peregrinaje era la forma de viajar con la que el gobierno era más tolerante, ya que un permiso de viaje difícilmente podría ser denegado por razones religiosas. Por lo que el peregrinaje era un frecuente pretexto para viajar. Algunos de los peregrinajes constituían enormes cantidades de personas, alcanzando alrededor de 400.000 a 500.000 en estaciones concretas, como el año nuevo". (8)

Es en la figura 5, elaborada a partir de los documentos gráficos de Moronobu, donde se entiende la jerarquía de los núcleos urbanos y su gran proximidad. La figura demuestra la densidad urbana de la llamada en esta investigación ciudad lineal.

became a continuous street with buildings on both sides in much of its layout. In figure 6 [Fig. 3 scaled-up] this built pedestrian corridor is clearly distinguished where three station-cities and twelve villages form a linear urban continuum of $15 \mathrm{~km}$ in length. The map, seen in detail, is not only a cartographic guide for the traveller but it is a true pictorial story where the human figures in movement represent the interurban mobility at that time, mobility based on walking, as the drawing of Moronobu attests.

City-Country Transition. The cities were long strips of buildings aligned on both sides of the route, which reached several kilometres in length. The buildings constructed a narrow corridor that isolated the traveller from the cultivated landscape of the valleys that stretched behind the many hotels and shops. The lodgings and the houses formed a chain of buildings lining the road, forming a narrow passage no more than 15 meters wide, and extended towards the rear spaces adding pavilions built between gardens, constructing a beautiful transition between the city and countryside.

In figure 7, the station-city of Futagawa ( $\left.\mathrm{n}^{\circ} 33\right), 280 \mathrm{~km}$ from Edo, crosses a deep valley from east to west. To the north, the mountains rise and, on their skirts, the temples (at that time authentic community centres) are placed outside the city. To the south, a river feeds the channels that irrigate the fields located on the edges of the linear city. The lodgings are located in the centre of the urban corridor and extend their housing pavilions perpendicularly, towards the orchards and gardens, and always facing south. (10) 
Corredor edificado peatonal. Un médico y naturalista alemán, Engerbelt Kaempfer, recorrió varias veces la ruta Tokaido entre 1690 y 1692, y tras volver a Europa dejó escrito un importante documento donde describió con sumo detalle lo que observó en el transcurso de sus viajes a lo largo de la ruta. Quedó fascinado por lo concurrida que estaba la carretera, tanto que en sus escritos la compara con la más populosa de las calles europeas. Kaempfer describe exactamente lo que corresponde con una ciudad lineal:

“[...] la mayoría de los pueblos consisten en una única larga calle, bordeando cada lado de la carretera, los pueblos a veces se extienden una longitud tal, que llegan a alcanzar el siguiente pueblo en un cuarto de milla (400 $\mathrm{m})$, más o menos". (9)

Kaempfer describe la ruta como un corredor edificado peatonal casi continuo, pues en ciertas ocasiones los límites de las poblaciones apenas distaban 400 metros, con lo que a poco que se extendieran las poblaciones a lo largo de la carretera, la ruta Tokaido se convertía en una calle continua con edificios a ambos lados en gran parte de su trazado. En la figura 6, [ampliación de la Fig. 3], se distingue con claridad este corredor edificado peatonal, donde tres ciudades estación y doce pueblos forman un continuo urbano lineal de $15 \mathrm{~km}$ de longitud. El mapa, visto en detalle, no solo es una guía cartográfica para el viajero, sino que es un auténtico relato pictórico donde las figuras humanas en movimiento representan la movilidad interurbana en aquella época, una movilidad fundamentada en la marcha a pie, y el dibujo de Moronobu así lo atestigua.

Transición ciudad-campo. Las ciudades eran largas tiras de edificios alineados a ambos lados de la ruta, que alcanzaban varios kilómetros de longitud. Los edificios construían un corredor estrecho que aislaba al viajero del paisaje cultivado de los valles que se extendían a espaldas de los numerosos hoteles y comercios. Los hospedajes y las viviendas formaban una cadena de edificios flanqueando el camino, formando un estrecho pasadizo de no más de 15 metros de anchura, y se extendían hacia los espacios traseros aña-
Fig. 6. Tramo de $15 \mathrm{~km}$ de la ruta Tokaido, entre las estaciones de Hara y Namara. Elaboración de los autores sobre los planos base: Tokaido bunkenzu 1-bu o motte 1-cho ni ateru. Genroku 3, por Hishikawa Moronobu, 1690 . Montaje de 73 planos incluidos en el volumen formado por 5 secciones. Tokyo National Museum.

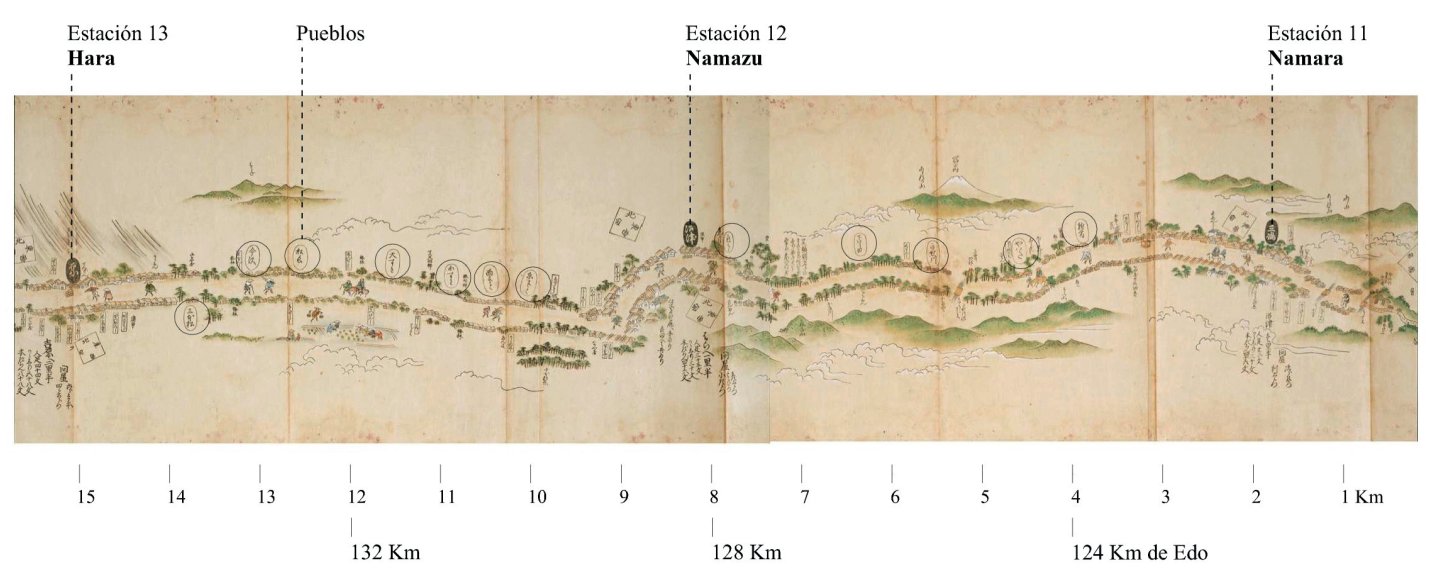




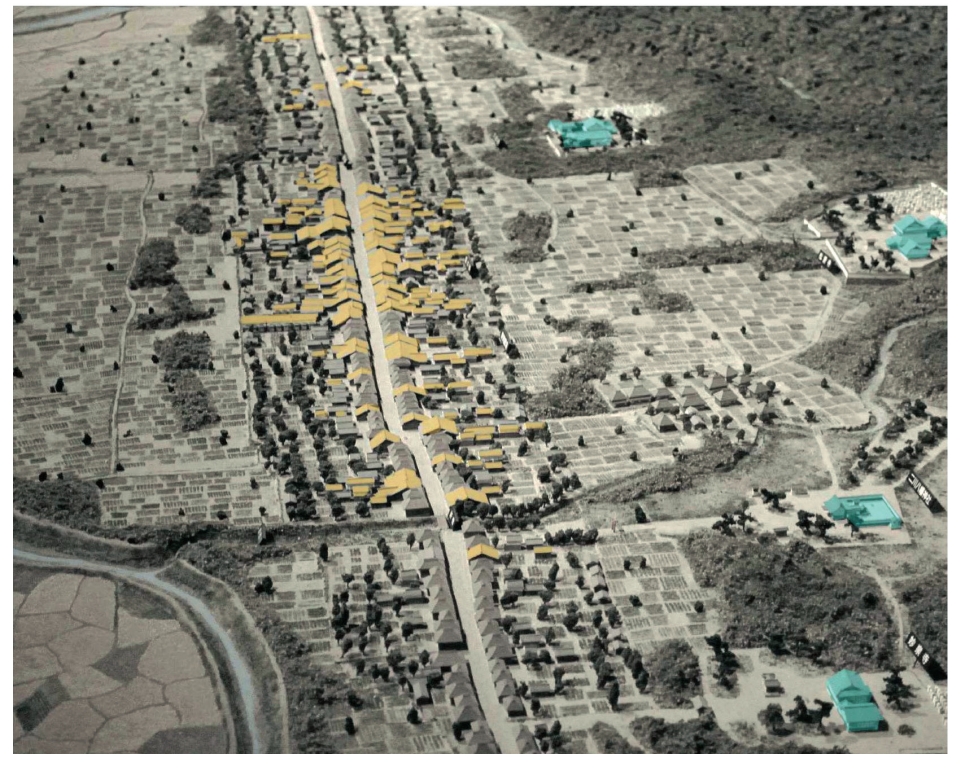

diendo pabellones construidos entre jardines, construyendo una hermosa transición entre la ciudad y el campo.

En la figura 7, la ciudad-estación de Futagawa (n. 33), a 280 km de Edo, atraviesa un profundo valle de este a oeste. Al norte se levantan las montañas y en sus faldas se acomodan los templos (en aquella época auténticos centros comunitarios) en una posición externa a la ciudad. $\mathrm{Al}$ sur serpentea un río del que nacen los canales que irrigan los campos situados en los bordes de la ciudad lineal. Los hospedajes se sitúan en el centro del corredor urbano y extienden sus pabellones de alojamientos en perpendicular, hacia las huertas y jardines, y siempre orientándose hacia el sur. (10)

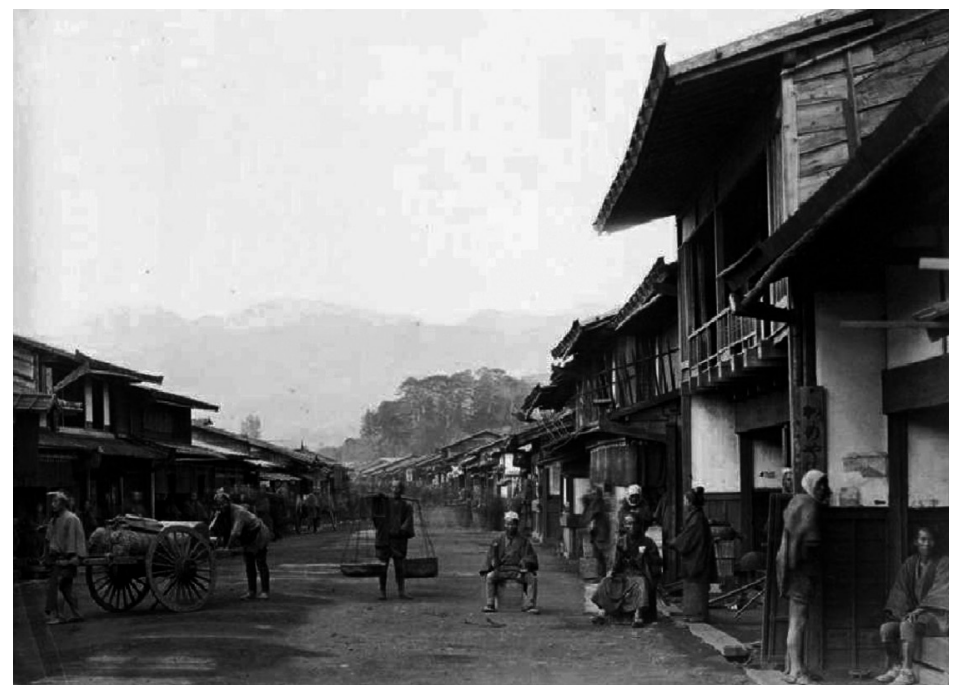

Fig. 7. Ciudad lineal en la carretera Tokaido en la época Edo. Ciudad-estación n. 33, Futagawa. Fotografía de maqueta perteneciente al museo Futagawa Shuku Honjin. Panoramio. En azul: Templos. En amarillo: Alojamiento para viajeros.
Fig. 8. Felice Beato. Ciudad lineal en la carretera Tokaido en la época Edo. Ciudad-estación n. 9, Odawara, ca. 1870. New York Public Library, col. Views of Japan. 
Pasadizo. La carretera Tokaido fue un espacio a modo de pasadizo durante muchos de sus tramos y durante decenas de kilómetros. El viaje a pie a través de este corredor infinito fue fotografiado por Felice Beato muy pocos años después de la caída del régimen feudal. (11) Sus fotografías relatan una época a punto de extinguirse y es por ello que son una documentación valiosa para la inmersión espacial en la ciudad lineal de Tokaido.

La figura 8 es una fotografía de Felice Beato de la ciudad lineal de Odawara; (12) el espacio es como un pasadizo urbano que se pierde en la lejanía, las edificaciones de madera en sus bordes no superan las dos plantas y se abren completamente al exterior en planta baja. Ambas caras del pasadizo son un escaparate continuo pero profundo ya que debido al carácter abierto de la planta baja, el espacio de la vía se extiende hacia el interior de los edificios, y viceversa. Beato nos ha permitido ser testigos de esta maravilla urbana en su máximo esplendor justo antes de su meteórica decadencia.

El siglo xx trae consigo un cambio fundamental en la movilidad urbana e interurbana. Doce días se tardaba en recorrer a pie la distancia entre Edo y Kioto, viajando por la ruta Tokaido. (13) Tras la abolición en 1869 del sistema feudal de control de carreteras y la finalización del ferrocarril Tokaido en 1889, siguiendo de cerca la antigua ruta, el viaje entre ambas capitales se redujo a 20 horas, y hoy se puede realizar el trayecto en tan solo 3 horas. La ciudad lineal peatonal desapareció en pocos años pero sentó las bases de la ocupación del territorio, y el inicio de la megalópolis de Tokaido.

Passageway. The Tokaido road was a space in the form of a passageway on many of its stretches along tens of kilometres. Few years after the fall of the feudal regime Felice Beato photographed the journey on foot along this infinite corridor. (11) His photographs tell time about to become extinct and as a result, are valuable documentation for spatial immersion in the Linear City of Tokaido.

Figure 8 is a photograph taken by Felice Beato of the Odawara line city; (12) space is like an urban passageway that is lost in the distance, the wooden buildings on its edges do not exceed the two floors and completely open to the outside on the ground floor. Both sides of the passageway are a continuous but deep showcase due to the open character of the ground floor, the space of the track extends into the interior of the buildings, and vice versa. Beato has enabled us to witness this urban wonder in its maximum splendour just before its meteoric decline.

The 20th Century brings a fundamental change in urban and interurban mobility. It used to take twelve days on foot to travel the distance between Edo and Kyoto on the Tokaido route. (13) After the abolition in 1869 of the feudal road control system and the completion of the Tokaido railway in 1889 , following the old route closely, the trip between both capitals was reduced to 20 hours, and today the journey can be made in just three. The linear pedestrian city disappeared in a few years but laid the foundations for the occupation of the territory, and the beginning of the Tokaido megalopolis. 


\section{NOTAS}

1. En 2005 la longitud total de autopistas nacionales niponas era de $7.560 \mathrm{~km}$, y planean alcanzar los $11.520 \mathrm{~km}$ de longitud cuando el sistema en red esté finalizado (España tiene $14.701 \mathrm{~km}$ de autopistas y autovías, la mayor red de Europa por delante de Alemania). El sistema radial en el siglo XVI llegó a tener alrededor de $6.500 \mathrm{~km}$ de longitud, mientras que el sistema circular apenas superaba los $1000 \mathrm{~km}$. Véase: MINISTRY OF LAND, INFRASTRUCTURE, TRANSPORT AND TOURISM. 'Chapter 5. History of road construction'. Annual Road Statistics Report. Tokyo: TMG, Tokyo Metropolitan Government, 2010, pp. 30-35.

2. J.M. Cabeza Lainez define el espacio oriental "constituido por elementos parecidos a hi-los, donde la característica fundamental del espacio urbano en Japón es la falta de plazas en sentido europeo, y su carácter lineal".

CABEZA, José María. 'La ciudad japonesa: Ascenso y declive de las megalópolis'. En: CID, Fernando (coord.). ¿Qué es Japón? Introducción a la cultura japonesa. Cáceres: Universidad de Extremadura, Servicio de Publicaciones, 2009, pp. 187-216.

3. La ruta norte se llamaba Nakasendo (carretera de montaña) y la ruta sur Tokaido (carretera de costa).

4. "En la era antes del teléfono y el telégrafo, lo mensajes oficiales eran llevados por mensajeros (hikyaku, pies voladores). Un mensajero portaba cartas, dinero o pequeños paquetes en un palo sobre sus hombros. Era más rápido de lo que pueda parecer; un paquete podría ser llevado de Edo a Kyoto en 90 horas". NAITO, Akira. Edo, the city that became Tokyo. An illustrated history. Tokyo: Kodansha International, 2003, p. 69.

5. Hishikawa Moronobu (1618-1694), artista fundamental del movimiento pictórico Ukiyo-e. El título original del mapa es Tokaido Bunke Ezu que se traduce como "Documento gráfico de la carretera de costa". Aunque existen otros mapas pictóricos anteriores que muestran la ruta Tokaido, el mapa de Moronubu es una obra maestra en su género.

6. Arturo Soria apenas construyó $5,2 \mathrm{~km}$ de los $58 \mathrm{~km}$ de la ciudad lineal que iba a ro-dear Madrid, y Hilberseimer, junto a Mies Van der Rohe, únicamente construyó una unidad vecinal de su ciudad lineal en Detroit en 1961,

Lafayette Park.

7. Un año alterno los señores feudales (260 aproximadamente) eran obligados a residir en Edo junto a sus familias, que permanecían 'secuestradas' en lujosas viviendas en los alrededores del Palacio Imperial. Esto suponía que decenas de comitivas de más de $\mathbf{2 0 . 0 0 0}$ hombres viajaran anualmente por la ruta Tokaido en cumplimiento de la ley, llamada Sankin Kotai (Sistema de residencia alterna). Véase: MIKISO, Hane. 'El gobierno Tokugawa. Los habitantes de las ciudades'. En Breve historia de Japón. Madrid: Alianza Editorial, 2011.

8. TRAGANOU, Jilly. The Tokaido road. Travelling and Representation in Edo and Meiji Japan. New York: Routledge Curzon, 2004, p. 72.

9. KAEMPFER, Engelbert. The history of Japan. Londres, 1727. Publicado y traducido del holandés por F. G. Scheuchzer. Párrafo incluido en 'Of the great Numbers of people, who daily travel on the Roads'. Chap. V, p. 429.

10. Los hospedajes para viajeros o Hatago (cesta de viaje, literalmente), eran edificios compuestos por pabellones dando a pequeños patios y jardines en la zona posterior de la parcela. Al frente se disponía de un volumen de acceso paralelo a la carretera que recuperaba el frente de la edificación y creaba el espacio tubo que se aprecia en la figura 8. Si el lector desea información detallada acerca de las tipologías que formaban la ciudad lineal puede consultar: TAKAHASHI, Yasuo; YOSHIDA, Nobuyuki; MIYA-MOTO, Masaaki; ITO, Takeshi (ed.) Zushū Nihon-toshi-shi. An Illustrated History of Japanese Cities. Tokyo: Tokyo University Press, 1994, p. 261.

11. Felice Beato (1833-1909), fue un fotógrafo inglés, nacido en Italia, que retrató la sociedad japonesa al comienzo de la restauración Meiji (1867-1912), una época de ocaso y cambio de ciclo. En su trabajo destacan las impresionantes vistas panorámicas de Edo y otras ciudades japonesas.

12. Odawara: estación n. 6. Recuérdese que esta estación aloja a más de 5.000 habitan-tes y posee alrededor de 1.500 edificios en línea, de los cuales 100 son hoteles (Hatago).

13. TRAGANOU, Jilly. 'The Tokaido. Scenes from Edo to Meiji Eras' Japan Railway \& Transport Review, n. 13, sept. 1997, p. 17.

\section{NOTES}

1. In 2005 the total length of Japanese national highways was $7560 \mathrm{~km}$. and it is planned to reach $11520 \mathrm{~km}$ in length when the network system is finished. (Spain has $14701 \mathrm{~km}$ of highways and motorways, the largest network in Europe ahead of Germany). The radial system in the 16th Century came to be around $6500 \mathrm{~km}$ in length, while the circular system barely exceeded $1000 \mathrm{~km}$. See: MINISTRY OF LAND, INFRASTRUCTURE, TRANSPORT AND TOURISM. 'Chapter 5. History of Road Construction' Annual Road Statistics Report. Tokio: TMG, Tokyo Metropolitan Government, 2010, pp. 30-35.

2. J. M. Cabeza Lainez defines the eastern space as "made up by threadlike elements, where the fundamental characteristic of urban space in Japan is the lack of places in the European sense and its linear character". In: CABEZA, José María. 'La ciudad japonesa: Ascenso y declive de las megalópolis'. In: CID, Fernando. (coord.). ¿Qué es Japón? Introducción a la cultura japonesa. Cáceres: Universidad de Extremadura, Servicio de Publicaciones, 2009, pp. 187-216.

3. The north route was called Nakasendo (mountain road) and the south route was called Tokaido (coastal road).

4. "In the era before the telephone and the telegraph, the official messages were carried by messengers (hikyaku, flying feet). A messenger carried letters, money or small packages on a stick on his shoulders. It was faster than it might seem; a package could be taken from Edo to Kyoto in 90 hours". NAITO, Akira. Edo, the City that Became Tokyo. An Illustrated history. Tokyo: Kodansha International, 2003, p. 69.

5. Hishikawa Moronobu (1618-1694), fundamental artist of the Ukiyo-e pictorial movement. The original title of the map is Tokaido Bunke Ezu which translates as "Graphic document of the coastal road". Although other previous pictorial maps show the Tokaido route, the Moronubu Map is a masterpiece of its kind.

6. Arturo Soria barely built $5,2 \mathrm{~km}$ of the $58 \mathrm{~km}$ of the Linear City that was going to surround Madrid, and Hilberseimer, together with Mies Van der Rohe, only built a neighbourhood unit of his linear city in Detroit in 1961, Lafayette Park.

7. Every alternate year the feudal lords (approximately 260) were forced to reside in Edo with their families, who remained 'kidnapped' in luxurious homes around the Imperial Palace. This meant that dozens of delegations of more than 20000 men travelled annually on the Tokaido route in compliance with the law, called Sankin Kotai (Alternate Residence System). See: MISIKO, Hane. 'El gobierno Tokugawa. Los habitantes de las ciudades'. In Breve historia de Japón. Madrid: Alianza Editorial, 2011.

8. TRAGANOU, Jilly. The Tokaido Road. Travelling and Representation in Edo and Meiji Japan. New York: Routledge Curzon, 2004, p. 72.

9. KAEMPFER, Engelbert. The History of Japan. London, 1727. Paragraph included in 'Of the great numbers of people, who daily travel on the roads', Chap. V, p. 429.

10. Lodgings for travellers or Hatago (basket for travel, literally), were buildings made up of pavilions overlooking small patios and gardens in the back area of the plot. To the front, there was an entrance volume parallel to the road that recovered the front of the building and created the tube space that can be seen in figure 8 . If the reader wishes more detailed information about the typologies that formed the linear city, consult: TAKAHASHI, Yasuo; YOSHIDA, Nobuyuki; MIYA-MOTO, Masaaki; ITO, Takeshi (ed.) Zushū Nihon-Toshi-shi. An Illustrated History of Japanese Cities. Tokyo: Tokyo University Press, 1994, p. 261.

11. Felice Beato (1833-1909) was an English photographer, born in Italy, who portrayed Japanese society at the beginning of the Meiji restoration (1867-1912), a time of downfall and cycle change, especially his stunning panoramic views of Edo and other Japanese cities.

12. Odawara: station n. 6 . Remember that this station hosts 5000 inhabitants having almost 1500 buildings in a row, 100 of them are hotels (Hatago).

13. TRAGANOU, Jilly. 'The Tokaido. Scenes from Edo to Meiji Eras'. Japan Railway \& Transport Review, n. 13, September, 1997, p. 17. 


\section{REFERENCIAS}

CABEZA, José María. 'La ciudad japonesa: Ascenso y declive de las megalópolis'. En: CID, Fernando (coord.). ¿Qué es Japón? Introducción a la cultura japonesa. Cáceres: Universidad de Extremadura, Servicio de Publicaciones, 2009.

KAEMPFER, Engelbert. The history of Japan. Londres, 1727. Publicado y traducido del holandés por F. G. Scheuchzer.

MIKISO, Hane. 'El gobierno Tokugawa. Los habitantes de las ciudades'. En: Breve historia de Japón. Madrid: Alianza Editorial, 2011.

MINISTRY OF LAND, INFRASTRUCTURE, TRANSPORT AND TOURISM.

Chapter 5. 'History of Road Construction'. Annual Road Statistics Report.

Tokio: TMG, Tokyo Metropolitan Government, 2010.

NAITO, Akira. Edo, the city that became Tokyo. An illustrated history. Tokyo: Ko-dansha International, 2003.

TAKAHASHI, Yasuo; YOSHIDA, Nobuyuki; MIYAMOTO, Masaaki; ITO, Takeshi (ed.). Zushü Nihon-toshi-shi. An Illustrated History of Japanese Cities. Tokyo: Tokyo University Press, 1994.

TRAGANOU, Jilly. The Tokaido road. Travelling and Representation in Edo and Meiji Japan. Nueva York: Routledge Curzon, 2004

TRAGANOU, Jilly. 'The Tokaido. Scenes from Edo to Meiji Eras'. Japan Railway \& Transport Review, n. 13, sept.1997, pp. 17-27.

\section{REFERENCES}

CABEZA, José María. 'La ciudad japonesa: Ascenso y declive de las megalópolis'. In: CID, Fernando (coord.). ¿Qué es Japón? Introducción a la cultura japonesa. Cáceres: Universidad de Extremadura, Servicio de Publicaciones, 2009.

KAEMPFER, Engelbert. The History of Japan. London: 1727. Published and translated from Dutch by F. G. Scheuchzer.

MIKISO, Hane. 'El gobierno Tokugawa. Los habitantes de las ciudades'. In: Breve historia de Japón. Madrid: Alianza Editorial, 2011.

MINISTRY OF LAND, INERASTRUCTURE, TRANSPORT AND TOURISM Chapter 5. History of Road Construction. Annual Road Statisfics Report. Tokyo: TMG, Tokyo Metropolitan Government, 2010. NAITO; Akira. Edo, the City that Became Tokyo. An illustrated History. Tokyo: Kodansha International, 2003.

TAKAHASHI, Yasuo; YOSHIDA, Nobuyuki; MIYAMOTO, Masaaki; ITO, Takeshi (ed.). Zushū Nihon-toshi-shi. An Illustrated History of Japanese Cities. Tokyo: Tokyo University Press, 1994.

TRAGANOU, Jilly. The Tokaido Road. Travelling and Representation in Edo and Meiji Japan. New York: Routledge Curzon, 2004.

TRAGANOU, Jilly. The Tokaido, Scenes from Edo to Meiji Eras. In: Japan Railway d Transport Review, n. 13, September 1997, pp. 17.27 .

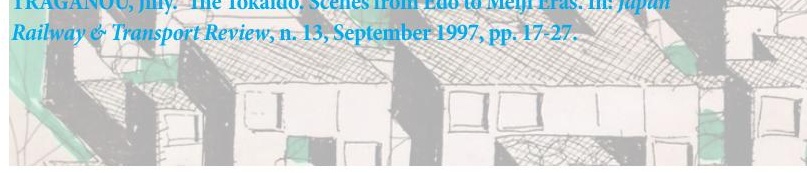

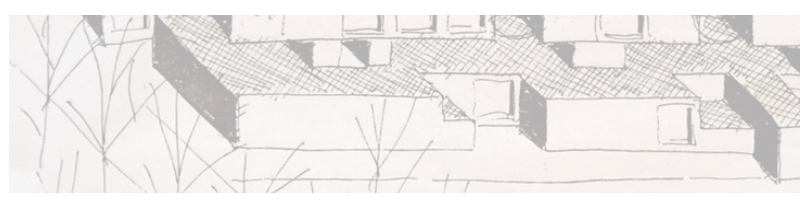

